\title{
Medea of Euripides and the Old Testament: Cultural critical remarks with special reference to the background of the Septuagint
}

Author:

Evangelia G. Dafni ${ }^{1,2}$ (1)

\section{Affiliations:}

${ }^{1}$ Department of Old Testament and Hebrew

Scriptures, Faculty of

Theology and Religion,

University of Pretoria,

Pretoria, South Africa

${ }^{2}$ Department of Pastoral and Social Theology, Aristotle University of Thessaloniki, Thessaloniki, Greece

\section{Corresponding author:} Evangelia G. Dafni, evangelia.dafni@uni-due.de

Dates:

Received: 20 May 2020 Accepted: 16 June 2020 Published: 29 Sept. 2020

How to cite this article: Dafni, E.G., 2020, 'Medea of Euripides and the Old Testament: Cultural critical remarks with special reference to the background of the Septuagint', HTS Teologiese Studies/ Theological Studies 76(4), a6145. https://doi.org/ 10.4102/hts.v76i4.6145

\section{Copyright:}

(c) 2020. The Authors. Licensee: AOSIS. This work is licensed under the Creative Commons Attribution License.
This article expands upon the range of options and methods of some of my earlier studies on Euripides and the Old Testament. These studies have sought to discover similar linguistic features and concepts in the texts of Euripides and the Old Testament, and to discuss how Euripidean tragedies can be read as Greek responses to Hebrew anthropological beliefs, more specifically as poetic-philosophical approaches to the anthropo-theological narratives of Genesis 2-4 and related biblical texts. These biblical texts probably transmitted through improvised oral or written Greek translations preceding the Septuagint (LXX), reorganise and transform the meaning of Hebrew expressions. This article presents the basic problems and aspects of a cultural-critical and comparative analysis and illustrates them with shared motifs from Medea, one of the eight Euripidean tragedies named after a female protagonist, and the Old Testament, thus expanding the boundaries of the traditional historic-critical exegesis.

Contribution: The article contributes to the investigation of the background of the Septuagint from a cultural critical perspective with special reference to the Euripidean tragedies.

Keywords: Human condition; Medea; Euripides; Old Testament; Septuagint.

\section{Introduction}

Medea (Med.), a masterpiece of Euripides performed in $431 \mathrm{BCE}$, left the deepest impact in the history of culture (Lesky 1972:300). It aims at portraying the feminine aspect of the human condition (Jaeger 1954:434). Medea, whose name means 'to know the wise advice', is the granddaughter of the sun god, Helios, and the greatest sorceress of Greek mythology. She is presented as someone who has access to advice from a supra-human dimension and can even conquer the powerful dragon. After the basic ethical principle of mutual love, which makes married life happy, is disregarded and abolished by her spouse, she asserts her female rights and goes beyond the limits of what is morally acceptable - she even slaughters her own children - so that she can free herself and achieve all her goals (ed. Eller 1983:132; Latacz 2003:281ff.).

Following Von Wilamowitz-Moellendorff (1880:406), Lesky (1972:301) assumes that the starting point of Medea's story was an old cult legend that told about an unintentional murder that she committed in trying to immortalise her children in the Corinthian temple of Hera (cf. Med. 1378). On the basis of this assumption, he asks whether Euripides or another author - probably Neophronwas the first to turn Medea into the vengeful killer of her own children. The controversy surrounding the background and the author of this tragedy in ancient and modern discussions (cf. ed. Eller 1983:131-169) leads to the widespread assumption of a combination of two important mythological oral traditions: (1) the tradition of the Argonauts that brought Medea with Jason and the Golden Fleece from Colchis at the Black Sea to Greece and (2) the tradition that brought Medea with Jason and her seven sons and daughters from Iolcus to Corinth to rule over the city. In a rebellion, the Corinthians killed the children of Medea, who had fled to the altar of Hera. However, Euripides redesigned these mythological traditions, added new features and painted the portrait of Medea killing her own two sons and being herself rescued by a dragon.

The questions that arise here are the following: what does the Euripidean tragedy Medea have to do with the Old Testament, which proclaims that Yahweh, the revealed God of Israel, will 'put enmity between' the serpent 'and the woman, and between its offspring and her offspring; he shall bruise' the 'head' of the serpent, 'and' the serpent 'shall bruise his heel'1 (Gn 3:15)?

1.Biblical text according to the English Standard Version (https://www.bibelwissenschaft.de/online-bibeln/english-standard-version/ bibeltext/).

Note: Special Collection entitled Septuagint SA, sub-edited by Johann Cook (SUN). 
What does profane Greek dramatic poetry have to do with Hebrew Holy Writ? With Johannes Hessen (21955:9ff.), we must admit that discerning the driving motives of two great intellectual systems and their confrontation with dominant and recurring images and ideas of completely different structures and origins is not an easy task. Only a long dealing with the genius of both cultures and challenging the preconception of Greek and Hebrew or Jewish intellectual insularity could create the conditions for the mental agility and proper vision required for fruitful critical cultural exploration.

\section{Slaughter or sacrifice of one's own children}

Firstly, it should be noted that finding comparable motifs regarding the slaughter of one's own children in Greek Drama and the Old Testament is not coincidence. However, these motifs are contextualised differently within the Greek polytheistic and Hebrew monotheistic frameworks. For example, in Genesis 22, Abraham is about to slaughter his only son and offer him for a burnt offering to God. In Judges 11, Jephthah the Gileadite sacrifices his only daughter to God after his tragic vow (cf. Dafni 2016), and in 2 and 4 Maccabees, the mother of the seven brothers encourages them to die as martyrs instead of living in godlessness (cf. Dafni 2015). Even the merciful God of the Old Testament, portrayed inter alia as the mother of his people (Is 46:3-4; cf. Mayer 2014), announces the killing of the sons of the wicked and the enemies of his law - regardless of whether they belong to his chosen people or not - 'because of the guilt of their father(s, MT)', so that there will be no offspring from them forever (Is 14:21; especially LXX in connection with Gn 3:15; cf. Dafni 2019:182, 187).

In the Euripidean tragedy Medea, Ino appears to be Medea's prototype, although Ino commits suicide. According to the chorus (Med.), Ino was the 'only one woman':

$[O] f$ all that have been,... who put her hand to her own children: Ino driven mad by the gods when [1285] Hera sent her forth to wander in madness from the house. The unhappy woman fell into the sea, impiously murdering her children. Stepping over the sea's edge, she perished with her two children. ${ }^{2}(1284-1289 \mathrm{ff}$.

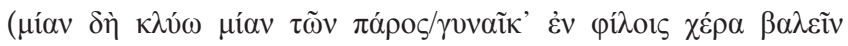

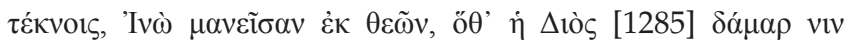

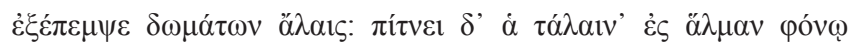

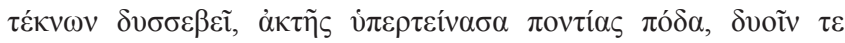
$\pi \alpha i \delta \delta o เ v ~ \sigma v v \theta \alpha v o v ̃ \sigma ' \alpha \jmath \operatorname{\alpha o} \lambda \lambda v \tau \alpha \imath)$. However, Medea's reason for killing her children is related neither to mental illness (madness) nor to the fear of being ridiculed (mocking laughter of her enemies), nor yet pure need (revenge of the Corinthians after the murder of their king and princess). The motivation behind her decision is clearly vengeance for being abandoned by her once beloved husband. According to the mythological background, this decision was not difficult for the female protagonist of the present Euripidean tragedy

2.I quote Medea's translation by David Kovacs (http://www. perseus.tufts.edu/ hopper/text?doc=Perseus\%3Atext\%3A1999.01.0114). because her whole story with Jason is inscribed with cruelty and cold, bloody deeds. For his love, Medea left her homeland and plotted the murder of her own father and brothers, as well as that of Jason's evil uncle, Pelias. In the Euripidean tragedy, Jason leaves Medea and marries the daughter of Creon, the king of Corinth, with the aim of becoming his successor and having other, royal children. Medea uses her charms to murder the king, his daughter and her own children so that Jason remains childless forever and no longer has a future. She also predicts his death according to the jus talionis (Med.):

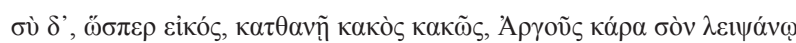

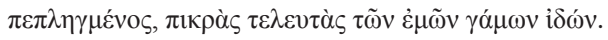

$[B]$ ut you, as is fitting, shall die the miserable death of a coward, struck on the head by a piece of the Argo, having seen the bitter result of your marriage to me. (1386-1388ff.)

With the aid of a dragon, sent by the sun god Helios, her grandfather, she flees to Athens. She finds asylum and a new home with the childless ${ }^{3}$ king Aigeus and promises him offspring.

The following similarities between Medea and Genesis 2-3, as regards the key figures, are noteworthy: in the Euripidean tragedy, the key figures are a woman and her man, a marriage, male children and dragons. In Genesis 2-3, a man and a woman from the same flesh become one flesh - a hint to a marriage and children, and a serpent strikes up a lethal conversation with the woman. Both cases are characterised by betrayal, abandonment and a change for the worse in the original human condition.

In LXX Isaiah, Yahweh Sebaoth appears as a mother (Is 46) who kills the sons of guilty fathers, who cause betrayal and abandonment of the belief in the true God of Israel. It is remarkable that these 'fathers' appear as mighty kings of Assyria (Is 10) and Babel (Is 14) who maliciously attack God's children like the cunning serpent of Genesis 3. In LXX Isaiah $27: 1$, the serpent is designated as 'dragon' ( $\oint \rho \alpha ́ \kappa \omega v)$, namely, 'the dragon, the fleeing serpent' and 'the dragon, the crooked serpent' that will be killed on that day by God's holy and great and strong sword (Dafni 2019:164-167). The eschatological texts of the LXX Isaiah reflect the language and imagery of the so-called Urgeschichte and express poetically how the original God-intended human condition will be restored at the end of world history.

\section{Towards the original human condition}

Genesis 2-3 depicts some interesting aspects of the human condition. According to Genesis 2:7, God formed man from

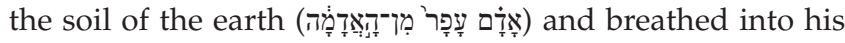

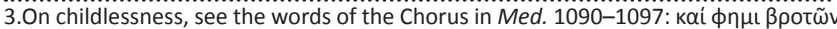

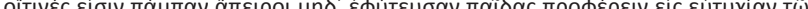
oit

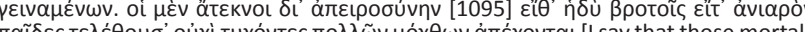
$\pi \alpha \tilde{I} \delta \varepsilon \varsigma \tau \varepsilon \lambda \varepsilon \boxminus$ ก who are utterly without experience of children and have never borne them have the advantage in good fortune over those who have. For the childless, because they do not possess children [1095] and do not know whether they are a pleasure or a vexation to mortals, hold themselves aloof from many griefs]. 
face a breath of life. Hereafter, the man became a living being. After God stated ' $[i] \mathrm{t}$ is not good that the man should be alone; I will make him a helper fit for him' (Gn 2:18), he took a rib from the man, fashioned it into a woman and brought her to the man. The man then perceived, identified and recognised the woman as 'bone of my bones' and 'flesh of my flesh' (Gn 2:22-24). The narrator comments that she shall be called 'woman', for she was taken out of her man (Dafni 2001a). And he adds (Gen 2):

$[T]$ herefore a man will leave his father and mother and will be joined to his wife (so NETS. MT \& LXX verbatim 'woman'), and the two will become one flesh. (v. 24)

After the intervention of the talking serpent, which was 'the wisest/most sagacious of all the wild animals that were upon the earth, which the Lord God had made', this original condition will be fundamentally changed. By appealing to immortality and divine wisdom, the serpent causes disorientation and confusion, which leads to breach of trust and faith in God. As a result, God says to the woman (Gn 3):

$[I]$ will increasingly increase your pains and your groaning; with pains you will bring forth children. And your recourse (abhorrence) will be to your husband, and he will dominate you. (v. 16)

As is well known, the pattern of a nuclear family (man-woman-child[ren]) and the theme of recourse to or abhorrence for a spouse recur throughout Hosea 1-2 as a salvation-historical image of Israel's behaviour towards his creator and saviour. The specific relationship of Hosea and his unfaithful wife and her children of whoredom symbolises the relationship between God and His unfaithful people, who abandoned Him and acted shamefully. The relationship of the unfaithful wife with her lovers (Hs 2:7ff.) represents the relationship of the unfaithful people of God, who pursue and seek the gods and the kings of the nations. However, Hosea states that God will not overtake and find them, until Israel realises that he has to repent and return in faithfulness to the merciful Lord of Israel (cf. Dafni 2001b).

An echo of the notions of leaving parents and being joined to a spouse (cf. Dafni 2007), breach of trust and marital faith, abhorrence, betrayal and abandonment can also be found in the prologue of the Euripidean tragedy (Med.):

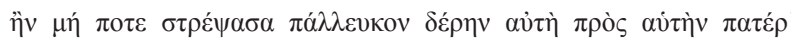

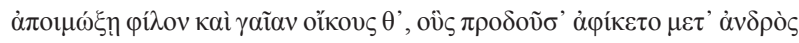

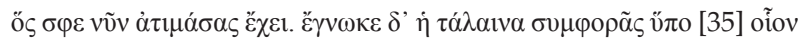

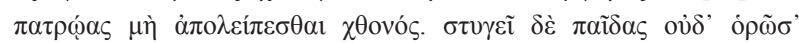

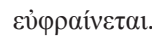

[She is silent unless perchance to turn her snow-white neck and weep to herself for her dear father and her country and her ancestral house. All these she abandoned when she came here with a man who has now cast her aside. The poor woman has learned at misfortune's hand [35] what a good thing it is not to be cut off from one's native land. She loathes the children and takes no joy in looking at them]. (30-35ff.)

4.I quote from now on the English translation of the Septuagint according to NETS (http://ccat.sas.upenn.edu/nets/edition/).
In comparison to Genesis 2-3, the roles here seem to be mirror-inverted. Euripides portrays Medea after the portrait of a man. Instead of a man leaving his father and mother, Euripides says that a woman, Medea, leaves her father, her own homeland and her ancestral house for the sake of a man. In fact, she proves to be intellectually and psychically superior to a man but at the same time is exposed to hatred and resentment in society (cf. Hose 2008:51; Lesky 1972:303). After Creon's commandment, she had to leave a house and a land again and become a fugitive with her two sons (Med. 271ff.). She could no longer return to her roots and did not yet know with whom she could take refuge. The chorus emphasises that the 'unhappy woman' has 'no father's home in which to find anchorage, ...., and another, a princess, greater match than herself, [445] holds sway in the house' (441-445: бoì $\delta$ '

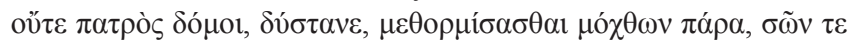

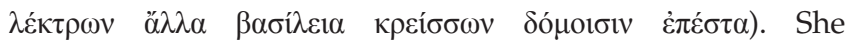
voluntarily abandoned her own roots, her father and her paternal royal home and followed Jason as her husband but not as a king's wife to his own royal house, because Jason was not the king of Corinth. However, the new house never became her own home. Jason despised Medea's royal origin and dignity, installed another woman from a royal family as legal spouse with the aim of begetting other, royal children. Losing her husband's love (286) and seeing her children being held in contempt by their own father hurts Medea. Her banishment somehow recalls the biblical case of Sarah, the childless wife of Abraham, and her Egyptian slave-girl Hagar. After Sarah's suggestion that Abraham should take her as 'wife', Hagar conceived Abraham's son Ishmael. Sarah felt that Hagar held her in contempt and Hagar fled from her mistress. However, the angel of God instructed her in the wilderness to return to Sarah and give birth to the child (Gn 16). But Medea has no place to lay her head.

The above-mentioned biblical and mythological cases are about disturbed marriage and family relations. Genesis 2:23-24, however, represents the original relationship between man and woman as endowed by God. Medea seems to have this interpretation of marriage in mind as she fights for her rights. New questions arise from the comparison of the originally divinely ordained human condition in the form of the chain man-woman-one flesh with its social realisation in history. (1) What happens if a man and a woman come from foreign countries? (2) What happens if one or the other or both spouses are bad? (3) What happens if it does not work at all as it was originally intended to be? It then has to be asked whether man or woman should seek retribution against the spouse in the name of a supreme god who witnesses and preserves the oaths of marriage? The biblical texts and the present Euripidean tragedy seek to come intellectually closer in their answers.

\section{The anthropological chain of man- woman-one flesh}

Biblical narratives and Wisdom literature distinguish between good and evil women in the history of the chosen people. The Euripidean Medea recognises the difference between evil and 
good men (Med. 235f.). It is surprising how Euripides presents the image of men and women from Medea's perspective and explains why she is mentally and psychically superior to men. Even more remarkable is the metaphorical and rhetorical way in which the Euripidean Medea uses language to define herself as a woman within the framework of marriage and family. She accuses Jason of unmanliness (Med. 465ff.) because he left her for another woman, a rich one and renounced their children. She declares him the arch-villain and the worst enemy of the gods, herself and the whole human race, thus emphasising that her personal fate is a universal affair of immeasurable moral consequences. In this way, Euripides shows that his ultimate goal is not simply to describe an individual event as credible, as the myth itself, but to describe repetitive or repeatable facts of fundamental importance for all mankind that echo through time (Med.):

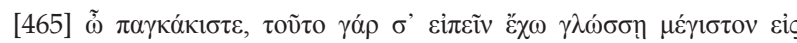

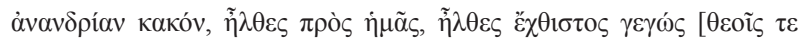

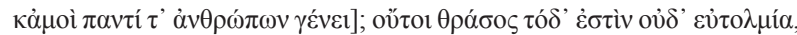

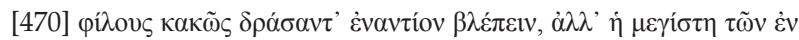

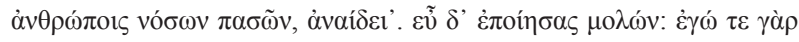

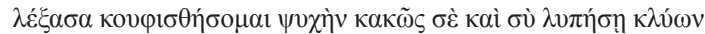

[465] Vilest of knaves - for that is the worst insult my tongue can speak against your lack of manly worth - have you really come to see me when you have made yourself my worst enemy [to the gods, to me, and to the whole human race]? This is not boldness or courage - [470] to wrong your loved ones and then look them in the face - but the worst of all mortal vices, shamelessness. But you did well to come, for it will relieve my feelings to tell you how wicked you are, and you will be stung by what I have to say. (465-470ff.)

The Euripidean term ảv $\alpha v \delta \rho i \alpha^{5}$ [unmanliness, lack of manly worth], which characterises Jason's insulting act towards Medea as an offense against humanity, recalls the wordplay שיאמי ינכ הדָשִא in MT-Genesis 2:23. Symmachus renders the

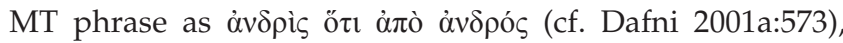
which points to the original equality and mutual responsibility of both human genders given by God (Bratsiotis 1973:242f. and n. 32).

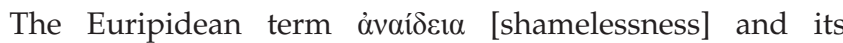

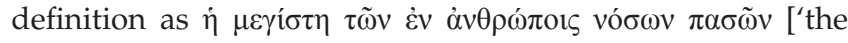
worst of all mortal vices', verbatim 'the worst of all human diseases'] reminds us of man's attitude before God and the transgression of the divine commandment. This attitude is expressed in advance with the negated verbal form ouk

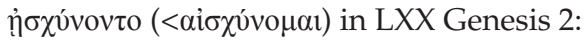

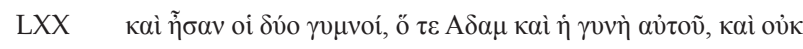

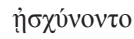

[NETS And the two were naked, both Adam and his wife, and were not ashamed.] (v. 25)

Lack of manly worth and shamelessness also characterise the words of the man before God in Genesis 3:10, 12, who does not take responsibility of his deeds and accuses directly the woman and indirectly God himself for his own sin or insult.

5.cf. ävavopos in 4 Maccabees 5:31, 6:21, 8:16 and 16:14.

\section{Genesis 3:}

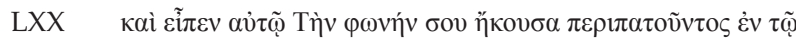

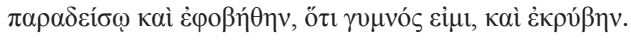

[NETS I heard the sound of you walking about in the orchard, and I was afraid, because I am naked, and I hid myself.] (v. 10)

\section{Genesis 3:}

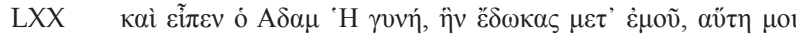

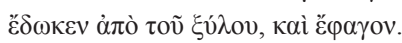

[NETS The woman, whom you gave to be with me, she gave me of the tree, and I ate.] (v. 12)

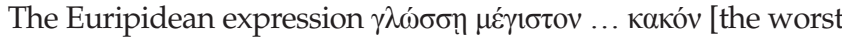
insult of the tongue] brings to mind the role of talking and eating in Genesis 3, specifically the fact that, with its words to the woman the serpent stirs up rebellion against God's commandment and leads both, man and woman, to the consumption of the forbidden fruit and to death. Medea argues that one who acts unfairly but is clever in speech deserves the

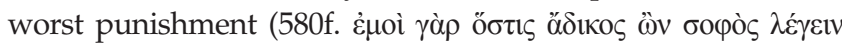

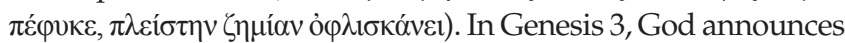
the ultimate punishment of the sagacious serpent that talks or rather acts with false words ungodly:

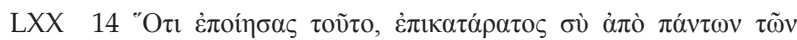

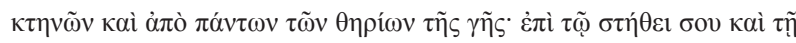

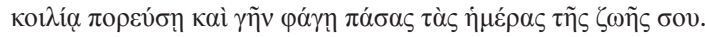

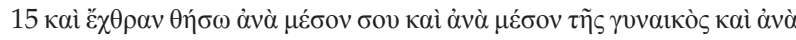

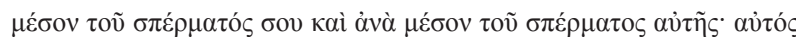

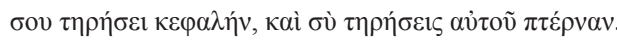

[NETS 14 Because you have done this, cursed are you from all the domestic animals and from all the wild animals of the earth; upon your chest and belly you shall go, and earth you shall eat all the days of your life.

15 And I will put enmity between you and between the woman and between your offspring and between her offspring; he will watch your head, and you will watch his heel.] (vv. 14-15)

At this point, it might be said that Genesis 3 and Medea have the following leitmotifs in common: (1) the perpetrator will be brought to divine justice, (2) the curse of the perpetrator entails his total destruction and (3) the perpetrator will be first destroyed by the destruction of his entire offspring.

The talking serpent appears to be the moral perpetrator of the violation of God's command in Genesis 3. It is well known that the LXX translates the Hebrew word נחש with

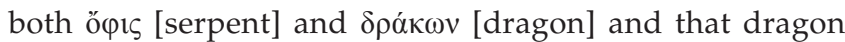
also means a huge serpent. The motif of the dragon occurs twice in the plot of the Euripidean tragedy: (1) Medea rescues Jason's life by disempowering the unconquerable dragon that guarded the Golden Fleece. (2) A dragon with a flying chariot sent by Helios rescues Medea from the rage of the Corinthians after the murder of their king, his daughter and the sons of Jason. In contrast to Genesis 3, where the woman, driven by the serpent, shares the forbidden fruit with her man and both drift into sin and death, a woman (Medea) claims that she rescued a man (Jason) from the dragon. 
In the second epeisodion, Medea recapitulates what she has done for Jason's love (476-491) and emphasises that, after all these things, she could only accept Jason's desire for another woman and a new marriage for one single reason: childlessness (Med.; cf. footnote 3):

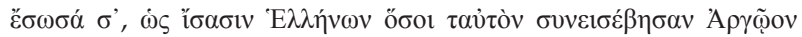

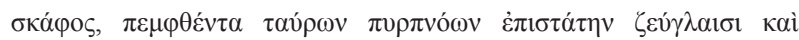

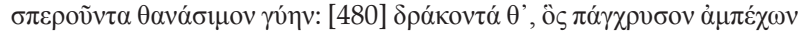

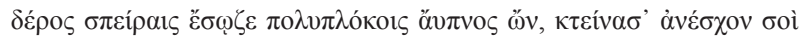

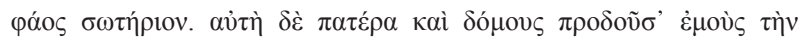

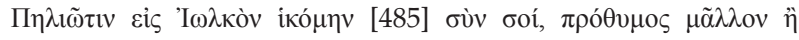

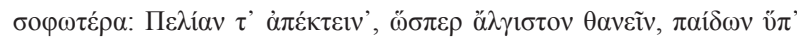

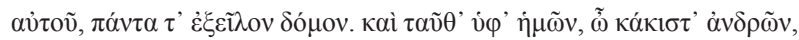

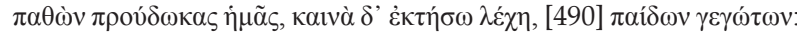

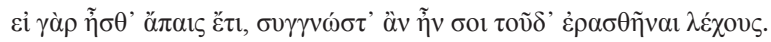

[ I saved your life - as witness all the Greeks who went on board the Argo with you - when you were sent to master the firebreathing bulls with a yoke and to sow the field of death. [480] The dragon who kept watch over the Golden Fleece, sleeplessly guarding it with his sinuous coils, I killed, and I raised aloft for you the fair light of escape from death. Of my own accord I abandoned my father and my home and came with you to Iolcus under Pelion, [485] showing more love than sense. I murdered Pelias by the most horrible of deaths - at the hand of his own daughters - and I destroyed his whole house. And after such benefits from me, o basest of men, you have betrayed me and have taken a new marriage, [490] though we had children. For if you were still childless, your desire for this marriage would be understandable.] (476-491ff.)
\end{abstract}

According to the chorus, the major cause of marital infidelity and amorality is that 'the magical power of an oath has gone, and shame is no more [440] to be found in wide Hellas: she

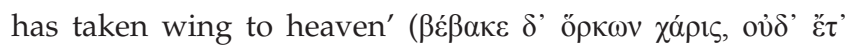

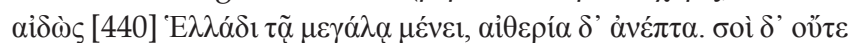

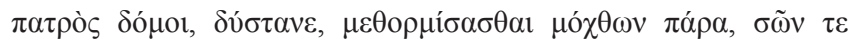

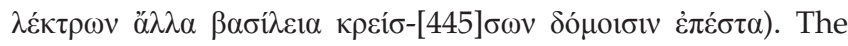
translation of David Kovacs allows the interpretation that magic no longer has a place in the philosophically enlightened Hellas of the 4th century BCE. But the Greek text disapproves of the lack of respect for the authority of the oaths and people's shamelessness.

In Genesis 2-3, shamelessness leads to rebellion against God followed by the rebels being cursed. The first man and his woman unashamedly ignore the divine bond between the creator and his creatures and follow the godless word of the serpent with the great expectation of being like gods. But what happens if one unashamedly ignores the wedding oaths and breaks the marital bonds? Medea calls upon Themis and Artemis to see what she has endured, although she has bound the accursed husband with holy oaths (Med. 161f.). She then appeals for retribution in the name of the supreme god, Zeus, who witnesses and preserves the wedding oaths. In the Euripidean tragedy, oath is bound to a curse. In Genesis 3-4, it is said that, in retaliation for disregarding God's will and for the humans' resultant ungodly deeds, (1) cursed is the serpent as God's and man's adversary 'from all the domestic animals and from all the wild animals of the earth' or land (3:14), (2) cursed is the earth in the labours of the man or Adam (3:17) and (3) cursed is a man (Cain) as brother-murderer 'from the earth' (4:11). Jason's godlessness and disrespected wedding oaths are the reasons why Medea desires retribution $(\mathrm{Med}$.):

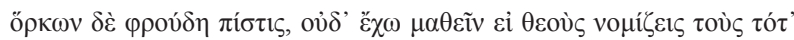

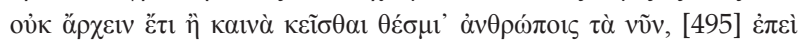

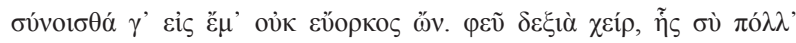

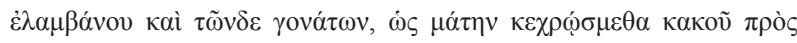

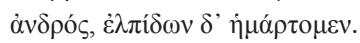

[Respect for your oaths is gone, and I cannot tell whether you think that the gods of old no longer rule or that new ordinances have now been set up for mortals, [495] since you are surely aware that you have not kept your oath to me]. (492-495ff.)

The nurse suspects that Medea could commit suicide (40) after punishing Creon and his daughter. She wishes (95):

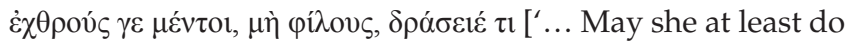
evil to the enemies, not the loved ones!']. However, Medea thinks of filicide and plots the death of all the perpetrators and their offspring. If she had committed suicide, she would have victimised herself for a second time, whilst the perpetrator would have been unpunished. Medea is totally aware that what she is about to do is a godless work (" $p$ prov

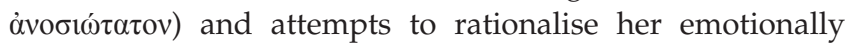
dominated wrongdoing, because she is absolutely convinced (800ff.) that she made a mistake, when she left her father's house, trusting the words of a mendacious and hypocrite Greek man. This man would now pay her penance as he would never see the children alive again in the future, nor would he receive a child from the newly married bride because she must die 'a wretched death' by Medea's magic means (806).

Jason thinks he might be excused of infidelity and marriagebreaking and assures Medea hypocritically (Med.):

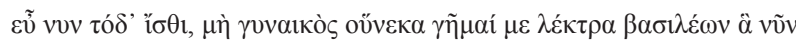

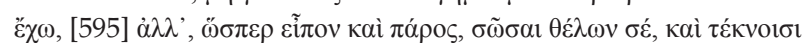

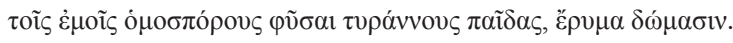

[It was not for the sake of a woman that I married the royal bride I now have, [595] but as I have just said, because I wanted to save you and to beget princes as brothers to my children, to be a bulwark for the house.] (593-597ff.)

He pretends to be deeply concerned for the safety of Medea and their children and offers money and his friends' support to help them in exile (610ff.). However, such a shameless excuse cannot claim to have moral support, as the children's old educator shows. He points to the key for the disturbed man-woman relationship, marriage and society and defines the quintessence of egoism or selfishness against the biblical moral principle 'love thy neighbour as thyself' ${ }^{6}$ as follows

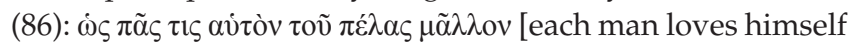
more than his neighbour]. This Euripidean definition of egoism regarding Medea and Jason is obviously later supplemented by the reasoning 'some justly, others for the

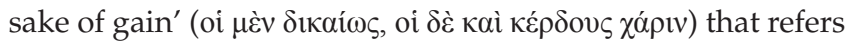
to Medea's right of self-defence and Jason's selfish craving 6.Leviticus 19:18, 34. Cf. Matthew 22:39/Mark 12:31, Romer 13:9, Galater 5:14 and Jacobus 2:8. 
for money and social prestige (87ff.). The implication of selfishness for the sake of gain occurs in the tragedy over and over again because, instead of gratitude and honour, ingratitude and dishonouring of friends rule overall. Therefore, the chorus wishes (Med.):

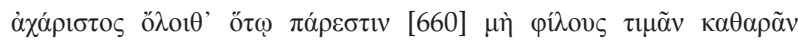

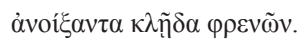

[May that man die unloved who cannot [660] honor his friends, unlocking to them his honest mind]. (657ff.)

Jason is cursed because of disrespecting wedding oaths and dishonouring his wife and children but so are his own children. They are thought to be cursed like the offspring of the serpent (Gn 3:14f.; cf. Is 14:20). Medea laments loudly

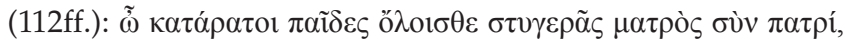

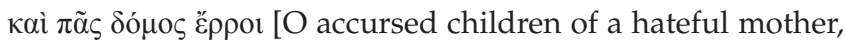
may you perish with your father and the whole house collapse in ruin!]. The nurse then asks why the children are hated and accursed along with their father (116f.): $\tau i$ $\delta \varepsilon$ $\sigma 01$

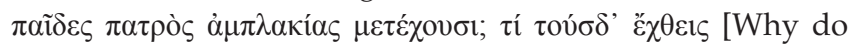
you make the children sharers in their father's sin? Why do you hate them?]. The question as to whether or not the children are collectively morally guilty for the individual insult or sin of their father also arises in Ezekiel 18:2 ("The fathers ate unripe grapes, and the teeth of the children had pain?'; cf. MT Jr 31:29f.), where it is definitely denied with reference to individual responsibility and divine justice. However, in the Decalogue, Yahweh warns (Ex 20:5=Dt 5:9): 'I am the Lord your God, a jealous god, repaying the sins of fathers upon children to the third and fourth generation to those who hate $\mathrm{me}^{\prime}$. In the Euripidean tragedy, a jealous woman makes herself a god and threatens to repay the perpetrators and their offspring for having dishonoured her. The chorus wonders whether or not she will dare to kill the children and Medea (817) affirms that there is no other way to hit Jason the most. Otherwise, she must deliver the children to her enemies to insult them (1060f.).

Despite Medea's mood swings, one thing is very clear to her: as long as there would be children having both parents in common, the special bond between mother and father would remain unbreakable. Therefore, she must overcome her doubt and cowardice and kill those whom she had given birth (1063). Medea recognises the horror of what she intends to do but admits that her anger, which is to blame for mortals' greatest evils, is stronger than her rational thinking (Med. 1078-1080).

The tragedy reflects the notion that children being exterminated by their own mother means erasing injustice and the memory of deception and victimisation from Medea's mind as well as a nullification of the wedlock. This notion somehow inverts the notion of creatio ex nihilo in 2 Maccabees $7: 28$, where the mother of the seven martyrs captures the meaning of 'nothing' based on the thought of birth out of nothing and hopes for re-birth and resurrection by God who created and can re-create everything out of nothing.
Medea wants to destroy everything that reminds her of the broken wedlock and to create a new life at the side of a new, good husband.

\section{Women in marriage}

The Euripidean Medea represents, amongst other things, an examination of how Greek people in 4th century BCE saw women situated in history and society. It also represents how they perceived a woman's right to self-determination, namely, the right to physical and psychical integrity, as well as bodily and mental autonomy.

It is not a coincidence that the Euripidean Medea swears by Hecate, the goddess she worships most of all (395), that she will punish all who caused her pain and will not give anyone the joy of tearing her heart (397ff.). Hecate, the goddess of magic and sorcery, was closely associated with the protection and prosperity of Athenian households. By calling upon Hecate to witness to the truth of what she says and intends to do, Medea reflects her wish to be courageous in order to go to the worst (filicide) and not to be mocked. She summarises the offence against her and threatens the offenders with these

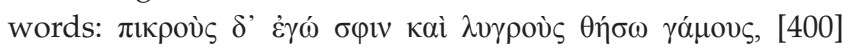

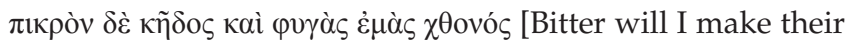
marriage, [400] bitter Creon's marriage-alliance, and bitter my banishment from the land!]. Then she gives a definition of woman's nature in the form of a short instructive saying

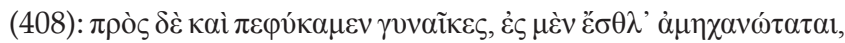

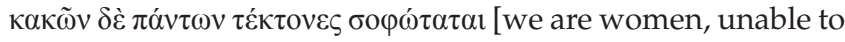
perform great deeds of valour, but most skilful architects of every evil]. Medea recognises, on the one hand, that women are by nature very untalented for noble deeds and, on the other hand, that women are very skilled workers in all evil ways. In this way, she reminds us of her earlier aphorism in

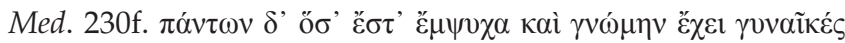

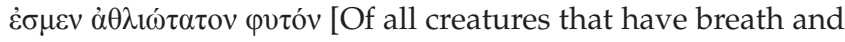
sensation, we women are the most unfortunate]. This aphorism initiates Medea's song before the chorus (230-251), which reveals the Euripidean criticism levelled at widespread ancient Greek views regarding the nature of women and their limited public role in the framework of marriage and family life. The reasoning behind Medea's aphorism that considers women for the most unfortunate growth of all animated creatures (230f.) is explained in Med. 232-251. The Greek adjective $\varepsilon \mu \psi v \chi 0 v,-\alpha$ (neutrum) points to Genesis 2:7,

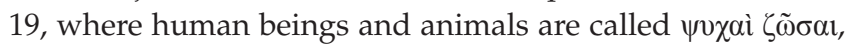
namely, living souls, that means 'animate beings'. The immediately following explanatory statements on dowry mean that marriage without love becomes a daily struggle for existence:

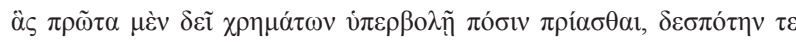

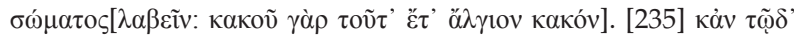

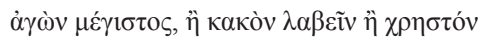

First at an exorbitant price we must buy a husband and master of our bodies. [This misfortune is more painful than misfortune.] [235] And the outcome of our life's striving hangs on this, whether we take a bad or a good husband. 
In marriage, a bride must bring her groom an amount of property and an excess of money, but gets only a master over her person in return (233ff.; Gn 3:16ff.). Medea's statements on the lack of women's self-determination in marriage seem to have as a starting point God's words to the woman after his commandment is transgressed in Genesis 3:16. According to the understanding of the LXX, the Lord says, ' $[a]$ nd your recourse will be to your husband, and he will dominate you'.

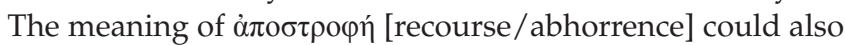

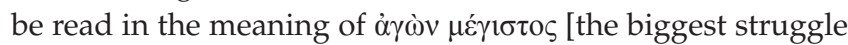
of all]. The outcome of a woman's life depends on getting either an evil or a good man as a husband (Gn 2:16; 236ff.). But Medea says (Med.):

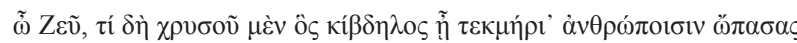

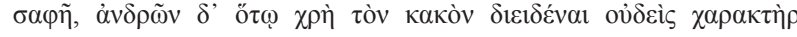
$\dot{\varepsilon} \mu \pi \dot{\varepsilon} \varphi v \kappa \varepsilon \sigma \omega ́ \mu \alpha \tau \imath ;$

[O Zeus, why, when you gave to men sure signs of gold that is counterfeit, is there no mark on the human body by which one could identify base men?] (516f.)

This Euripidean statement recalls Genesis 4:15. Yahweh,

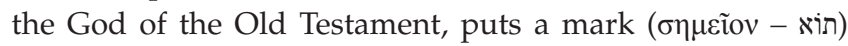
on Cain by which one could identify the brother-murderer and not attack him. Medea wishes there would be a sign so that a woman could recognise and avoid the evil man, especially because it was impossible for women to refuse marriage and divorce was thought to be bad and unacceptable. Amongst the issues dealing with the historical and cultural manifestations of fundamental roles of women in Greek society of 4 th century BCE is the fact that foreign women who come into new customs, traditions, conventions and laws cannot reject a man (Med.):

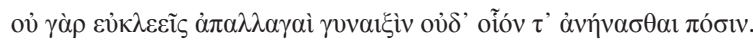

[For divorce is discreditable for women and it is not possible to refuse wedlock]. (236f.)

According to Medea, a woman must be a visionary because she has not learnt at home how to best deal with a bedfellow. If a woman then laboriously accomplishes this and the husband lives with her, voluntarily carrying the yoke with her, this life is enviable. If not, she should die (241ff.).

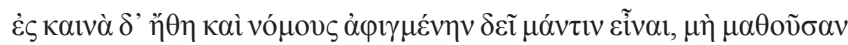

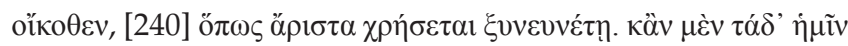

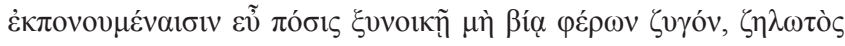

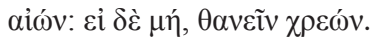

[And when a woman comes into the new customs and practices of her husband's house, she must somehow divine, because she has not learnt it at home, [240] how she shall best deal with her husband. If after we have spent great efforts on these tasks our husbands live with us without resenting the marriage - yoke, our life is enviable. Otherwise, death is preferable.]

Unlike a man tormented by his domestic circumstances, who goes outside and frees his heart from grief by turning to a friend or a peer, women are forced to focus on a single soul, namely, their own husband (244ff.).

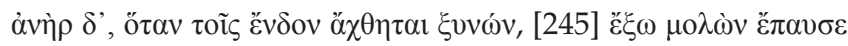

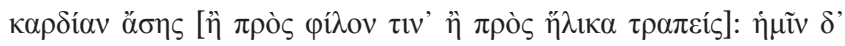

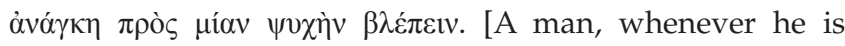
annoyed with the company of those in the house, [245] goes elsewhere and thus rids his soul of its boredom [turning to some male friend or age-mate]. But we must fix our gaze on one person only.]

The second part of the biblical statement ' $[a]$ nd your recourse will be to your husband, and he will dominate you' in Genesis 3:16 is inextricably linked with the first part of the statement on childbirth: 'I will increasingly increase your pains and your groaning'. In this sense, Medea states, men fight with the sword, women with the birth of their children:

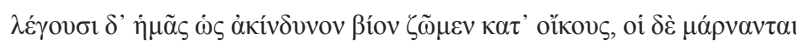

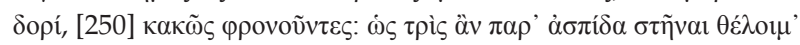

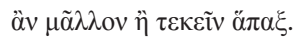

[Men say that we live a life free from danger at home whilst they fight with the spear. [250] How wrong they are! I would rather stand three times with a shield in battle than give birth once.] (250f.)

In a foreign land, a woman (Medea) is lonely, homeless, offended by a man and without a mother, brother, or relatives from whom she could seek refuge during misfortune (255-258). The Euripidean Medea recapitulates her situation as a foreign woman in a foreign world, by comparison to Jason as a man in his homeland, in the following way (Med.):

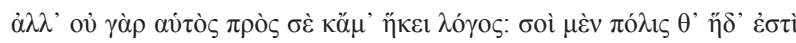

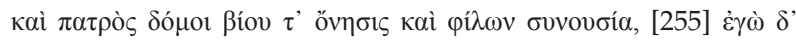

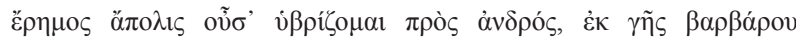

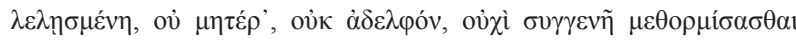

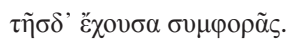

[But your story and mine are not the same: you have a city and a father's house, the enjoyment of life and the company of friends, [255] while I, without relatives or city, am suffering outrage from my husband. I was carried off as booty from a foreign land and have no mother, no brother, no kinsman to shelter me from this calamity. (252-258ff.)

Jason is presented as a traitor in marriage and a bad husband (206). He also cannot imagine the nature of women outside of marriage and family. From Jason's perspective, women do not bear misfortunes bravely and also tend to exaggerate fortune and misfortune. Women's uncontrolled temper is either at the zenith or it reaches the nadir. Consequently, (1) when marriage is right, women believe that they have everything, but when misfortune affects their married life, they consider the best and the most beautiful as the worst and most objectionable (569-574). (2) Misfortune reigns in the mortal world because there are women who give birth to children. (3) Men would somehow have to produce children by other means, without the existence of the female sex, so as not to suffer misfortune anymore (574-575). 


\section{Spouse-breaking}

The chorus makes a distinction between eros ("丷 $\rho \omega \varsigma)$ as the unconditional man's desire to conquer women, and marriage as a socially acknowledged union between a man and a woman that establishes rights and duties (Kú $\pi \rho ı \varsigma$ vs.

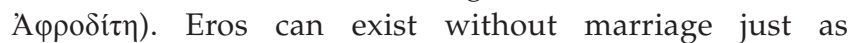
marriage can exist without eros. The chorus expresses the common understanding of marriage in connection with good reputation, moderation or modesty and virtue as follows (Med.):

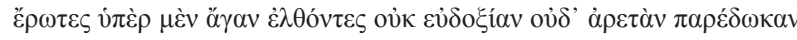

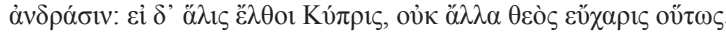

[Loves that come to us in excess bring no good name or goodness to men. If Aphrodite comes in moderation, no other goddess brings such happiness]. (627ff.)

The Euripidean Medea names money and the different cultural heritage of a married couple as the main causes of marriage-breaking. For her, marriage-breaking means the ultimate break of the biblical chain man-woman-one flesh which she cannot imagine without the connection to a homeland (cf. Gn 2:7). From Medea's perspective, the ultimate spouse-breaking could not only be achieved by forced displacement or by killing the new wife and her father in revenge, but also by exterminating the 'one flesh' and the whole future of the betrayer. Although she eradicates any future prospects for the adulterer, she creates a new life for herself by pleading Aigeus for protection. She asks him to take her in his land and in his house (713) and promises that she will end his childlessness and make him produce sons so that he can be happy all the days of his life (714-718; cf. Gn 3:15f.). In both cases, the biblical linkage between (1) human-being-homeland and (2) man-woman-one flesh is present.

Aigeus explains his willingness to support Medea (720-724). But for Medea, verbal promises are not enough if they are not sworn by the gods in oath. Therefore, she demands that Aigeus swears an oath by the plain of Earth, by Helios, her grandfather and by the whole race of the gods together (737) that he would never banish her from his land and that, if any of her enemies wish to take her, he would not willingly give her up as long as he lives ( $\mu \tau^{\prime} \tau^{\prime}$

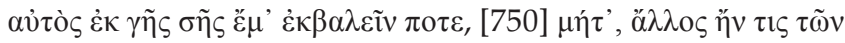

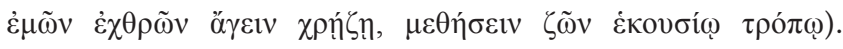
Consequently, he repeats her words and swears by Earth, by the holy light of Helios, and by all the gods that he will do what she demands. Should he not abide by his oath, he calls down on himself the punishment that befalls the

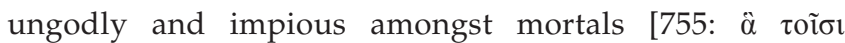

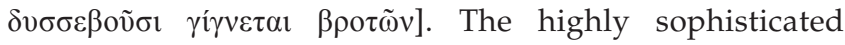
repetition of the oath in Med. 736f. and 749ff. indicates the polytheistic frame of the Euripidean critical look at marriage and spouse-breaking. The deeper meaning of the Euripidean playing with schemes that we are already familiar with from the biblical creation account, however, remains puzzling.

\section{Conclusion}

Euripides addresses similar or comparable issues with the Old Testament as contained in or originated from Genesis 2-4 and places them in a multicultural and polytheistic context. He indicates the connection between Genesis 2-4 and related biblical contexts and Medea in the prologue that begins with the if-not-sentences (1ff.), thus recalling the not-yet-sentences that introduce the second biblical anthropological account (Gn 2:5). Above all, he borrows the existential chains man-land or human beings-homeland (Gn 2:7) and man-woman-one flesh (Gn 2:23f.) and applies them in the case of Medea. The linguistic features, recurring motifs and concepts that the Old Testament and this Euripidean tragedy have in common would be unthinkable if an encounter of Hebrew and Greek thinking in the time before Euripides was excluded. The presence and circulation of improvised, oral or written Greek translations of Old Testament texts in the Greek-speaking world of the Classic period could probably be the answer to our primary question: what has Euripides's Medea to do with the Old Testament?

\section{Acknowledgements}

The author would like to thank Dr Helen Efthimiadis Keith-Van Wyk for reading the text and improving its language.

\section{Competing interests}

The author declares that she has no financial or personal relationships that may have inappropriately influenced her in writing this research article.

\section{Author's contributions}

E.G.D. is the sole author of this research article.

\section{Ethical considerations}

This article followed all ethical standards for research without direct contact with human or animal subjects.

\section{Funding information}

This research received no specific grant from any funding agency in the public, commercial or not-for-profit sectors.

\section{Data availability statement}

Data sharing is not applicable to this article as no new data were created or analysed in this study.

\section{Disclaimer}

The views and opinions expressed in this article are those of the author and do not necessarily reflect the official policy or position of any affiliated agency of the author.

\section{References}

Bratsiotis, N.P., 1973, איש, Theologisches Wörterbuch zum Alten Testament in G.J. Botterweck, H. Ringgren \& H.-J. Fabry (eds.), Bd I, pp. 238-252, W. Kohlhammer, Stuttgart. 


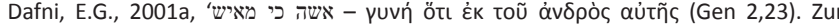
Anthropologie von Genesis 1-11', in A. Wenin (ed.), Studies in the book of Genesis: Aiterature, redaction and history, BETL 155, pp. 569-584, Peeters, Leuven.

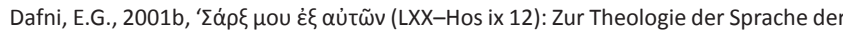
Septuaginta', Vetus Testamentum 51(1), 336-353.

Dafni, E.G., 2007, 'Genesis and Euripides: Exchange in virtue ethics between Israel and Hellas in the classical and Hellenistic period', Old Testament Essays 20(3), 601-615.

Dafni, E.G., 2015, 'Collective guilt and self-sacrifice in Sophocles' Antigone and II \& IV Maccabees: Preliminary cultural-critical remarks', Journal of Semitics 24(1), 198-215.

Dafni, E.G., 2016, 'Isaak, die Tochter Jephthas und Iphigenie: Menschenopfer im Alten Testament und im Alten Griechenland. Kulturkritische Beobachtungen unter besonderer Berücksichtigung der Septuaginta', in R.X. Gauthier, G.R. Gotze \& G.J. Steyn (eds.), Septuagint, sages, and scripture, Studies in Honour of Johann Cook, VTSup 172, pp. 1-30, Brill, Leiden.

Dafni, E.G., 2019, 'Die hoffärtigen Könige in Jesaja und Ezechiel: Zur Theologie de Sprache der Septuaginta', in E.G. Dafni (ed.), Gottesreich und Reiche der Menschen Studien zur Theologie der Septuaginta 2, WUNT 432, pp. 155-221, Mohr, Tübingen.
Eller, K.H. (ed.), 1983, Euripides: Medea, Griechisch/Deutsch, Reclam, Stuttgart.

Hessen, J., 1955, Platonismus und Prophetismus: Die antike und die biblische Geisteswelt in strukturvergleichender Betrachtung, Ernst Reinhardt Verlag, München.

Hose, M., 2008, Euripides: Der Dichter der Leidenschaften, C.H. Beck, München.

Jaeger, W., 1954, 'Euripides und seine Zeit', in W. Jaeger (ed.), Paideia: Die Formung des griechischen Menschen, Bd 1, pp. 419-449, Berlin.

Latacz, J., 2003, Einführung in die griechische Tragödie, Vandenhoeck und Ruprecht, Göttingen.

Lesky, A., 1972, Die Tragische Dichtung der Hellenen, Studienhefte zur Altertumswissenschaft 2, Vandenhoeck und Ruprecht, Göttingen.

Mayer, C.M., 2014, 'God's body and emotions: Gender perspectives on images of the divine in the Old Testament', Vetus Testamentum et Hellas 1, 22-45.

Von Wilamowitz-Moellendorff, U., 1880, 'Excurse zu Euripides Medeia', Hermes 15(14), 481-523. 